\title{
Natural gas transport system in the extended region of the Black Sea in the current geopolitical, geo-and geo-economics context
}

\author{
Alin-Nicușor CALOPEREANU \\ The Bucharest University of Economic Studies, Bucharest, Romania \\ Eugen PRIOTEASA \\ The Bucharest University of Economic Studies, Bucharest, Romania \\ eugen.prioteasa@yahoo.com \\ Ileana VĂLIMĂREANU (MIRCIOI) \\ The Bucharest University of Economic Studies, Bucharest, Romania
}

\begin{abstract}
Energy security as an integral part of economic security is seen by the involved actors from two perspectives: alternative sources and alternative energy routes, respectively as the interdependence between consumers and suppliers at all levels of the cycle of production, transport, distribution. The present article aims to present the existing realities of the transport routes of natural gas from the Extended Black Sea Region, and a brief analysis on the main projects outlined in this area in the context of contemporary challenges to global security. The methods used in elaboration of this article are documenting, analysis and synthesis.
\end{abstract}

Keywords: energy security, economic security, Black Sea Region, geo-economic challenges, natural gas distribution system, transport routes, geostrategic.

\section{Introduction}

International security is a fact that states that international organizations and other international actors contribute in different ways and to varying degrees. Interconnections of decisions and actions of international actors is, in the current conditions of globalization, increasingly more evident and more pronounced.

National security level is most commonly used in defining security. The state is the actor who assumes the role of security guarantor for individuals, groups and sometimes even regional security. Instead, state security is defined by the totality of political, economic, social, military and environmental necessary to guarantee the sovereignty, independence and promote national interests (Bărbuț, 2012).

For some specialists in the field, energy security is to be ensured in terms of resources, control and distribution routes and alternatives. In general, the concept is defined as "secure resources at a reasonable price" (Proninska, 2007), so it is integrated into a much broader issue than security of supply triangle - sustainability - competitiveness.

Terrorism, conflicts or natural disasters catches the attention of policy-makers, faced with the risks of supply, namely to ensure security of energy supply. Also, the focus is on the magnitude of the overcapacity to strategic reserves and surplus infrastructure. Therefore, prices and diversity of supply are critical components of energy security. (Bărbuț, 2012). 
In another vision, energy security means necessary energy production in their own country and minimized dependence on imports. But the realities of the current era have shown large consumers should renounce utopia energy independence and to accept energy interdependence (Băhnăreanu, 2008).

Today's energy policies are seen as measures that states or groups of states take towards ensuring security of energy supply, competitiveness of the energy industry and also environmental protection. Such a framework implies the need for cooperation between different conscious "energy players" (the state energy companies or consumers) to overcome difficulties related to these three components. A modern, clear and transparent Energy Policy must ensure a balance between the three objectives, managing to remove unwanted manifestation issues such as energy crises and ensure price stability in the sector and the continuity of supplies to consumers (Codoban, 2012).

Identified information sources relate mainly to official sources, press articles, a series of works about the geopolitical architecture of the extended region of the Black Sea. Most of the news articles are used to represent their respective author's opinion and have been cited in the documentation activity. The views presented in this paper represent our opinion in relation to the subject at the time of its elaboration, future developments may greatly vary in opposite directions.

Europe is facing a shortage of supply of energy resources and new transport routes are designed to eliminate this deficit and meet the requirements of growing consumption. Using the transit capacity of the Black Sea region is an essential step for its economic development and energy supply to Western and Southern Europe. Finding new routes to increase transport capacity of oil and gas from the Caspian basin is a requirement for economic development and meet the high consumption and the need for energy security of European countries.

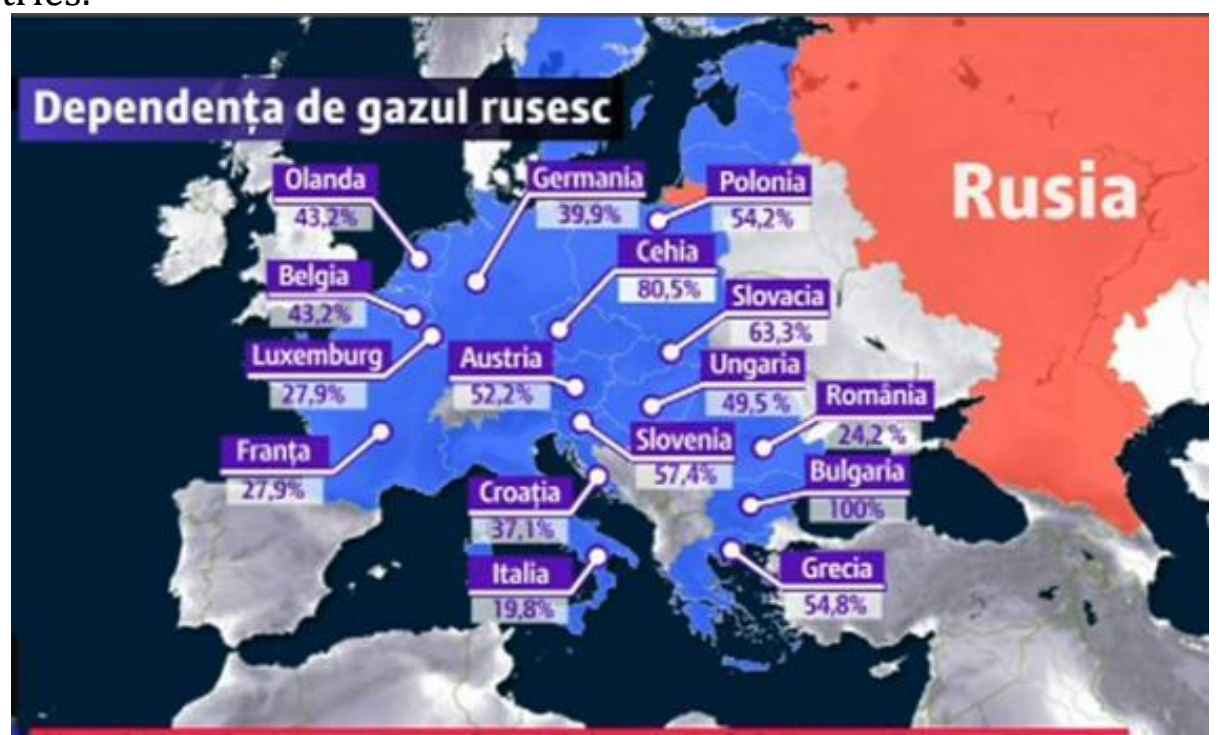

Figure 1. Dependence on imports of natural gas from Russia to Europe

Source: Postevka, 2010.

According to forecasts, in the EU will take place an increasing dependence on imports of natural gas from $57 \%$ currently to $84 \%$ in the year 2030 . Therefore, long-term energy policy of the European Union must take account of the need to carry out significant 
investments in its infrastructure, which would contribute to the security of gas supply to Europe (http://www.agrilng.com/ro).

\section{The EU's energy strategy}

On March 8, 2006, the EU has adopted a new draft energy strategy at Community level, the European strategy for Sustainable, competitive Energy and Safe (European Commission-An European Strategy for Sustainable, Competitive and Secure Energy, 8 of March 2006).

Directions for Action endorsed by the EU in order to ensure sustainability, competitiveness and security of energy are:

- ensuring the integrity of the internal market for gas and electricity, through the adoption of common rules and regulations, but also by building common network or connectivity to existing ones;

- Ensuring the security of energy flow and consolidation in this respect, solidarity between Member States, by reviewing national legislation on oil and gas stocks;

- diversification of energy sources;

- environmental protection and the promotion of energy-saving policies;

- creating a Strategic Technology Plan on energy;

- formulating a common foreign policy for all EU States, this identifies priorities for building a new infrastructure of power system protection;

- the adoption of a European Energy Treaty;

- adoption of a new energy partnership with Russia;

- creating a response mechanism in the event of a crisis caused by short-circuiting of Europe's energy supply.

Following the energy crisis of 2006-2007 (disruption of gas supply), the EU approved the European Union's new energy policy, with horizon 2020, which provides:

- reduce greenhouse gas emissions by $20 \%$ compared with 1990 ;

- increasing the share of renewable energy in the total energy mix from less than $7 \%$ in 2006, 20\% of all energy;

- increasing the share of biofuels to at least $10 \%$ of all fuels;

- reduction of primary energy consumption by 20\% (Bărbuț, 2012).

The EU has taken concrete steps toward building progressively an internal market in energy (energy security is to be achieved by reducing the significance of the geographical source of the gas supplied, once the common system of transport in the EU), which should be guaranteed access any citizen/community factors energy companies, adopting this legislative packages in years 1998, 2003 and 2009, targeting mainly the liberalization of national gas industries (Codoban, 2012).

Developments still not expressed concretely in all their consequences and backlog in 2014, prompted the European Council (March 2014) to request the European Commission to draw a detailed study on European energy security, which has resulted in developing a "Strategy on European energy security" adopted by the Commission on 28 May 2014 and discussed in the Council in June 2014 (Iordan-Constantinescu, 2014).

Noting that the energy security issues have been dealt with almost exclusively at the national level, the strategy adopts a "collective approach", through a functional internal market and greater cooperation at regional and European level ", but also by a "coherent external action "(Iordan-Constantinescu, 2014). 
The strategy is based on eight pillars, taking as a temporary horizon 2030:

- immediate action in order to enhance the capacity of the EU to overcome a major interruption of energy imports during the winter of 2014/2015;

- strengthening mechanisms for necessity/solidarity, including the conduct of risk assessments and contingency plans for infrastructure protection;

- moderating energy demand;

PICBE| 84

- achieving a fully integrated and functioning internal market;

- increased energy production in the EU;

- the development of energy technologies;

- diversification of foreign deliveries and related infrastructure;

- improved coordination of national policies on energy and the communication on a single voice in external energy policy (Iordan-Constantinescu, 2014).

We can say that the primary energy saving policies, in conjunction with decreased demand for energy, especially in the industrial area, due to the global economic crisis led to a balance in the quantities required in the European Union.

\section{The extended region of the Black Sea-area energy security in the European Union}

The Wider Black Sea areas include sea and land in Eastern and South-Eastern Europe, Caucasus and Near East; it is a crossing of the strategic directions and routes that ensures links between West and East, competition and cooperation among key international actors, between different socio-economic and sometimes conflicting value systems. After 2004, the Black Sea has been identified as the EU and NATO's eastern boundary, demarcation in the vicinity of the states of the CIS and the Collective Security Treaty Organization. (Postevska, 2010).

Energy security in the Black Sea extended area is defined in consonance with the two theories of commonly used internationally:

- The first theory refers to alternative routes and alternative sources of supply (i.e. alternating customers for the same resources);

- The second refers to the theory of interdependence, referring to the involvement of distributors in production processes or producers in the process of distribution or transit. (Chifu, 2011)

From the point of view of production / transit of natural gas, the main actors in the Black Sea region are:

- Russian Federation, with confirmed reserves of 47,000 billion cubic meters and an extensive network of pipelines through which natural gas exports to Europe or Asia. However, the main export pipeline to Europe transit countries such as Belarus, Ukraine, Lithuania, Poland respectively, implying some control from local carriers;

- Belarus it depends on economic and energy of the Russian Federation, having disputes with it in terms of prices of hydrocarbons. The transport system of natural gas is under the control of Gazprom;

- Ukraine has had numerous disputes with the Russian Federation related to gas transit or delivery price, culminating with the crises of 2009 and 2014 which endangered and gas supplies to the rest of Europe. (Mionel, 2015). Following the annexation of Crimea and the 
war in eastern Ukraine, Russian Federation dropped the gas storage capacities in Ukraine and seek alternative routes to bypass this state.

- Romania, a NATO and EU member, having a domestic production ensures that much of the necessary, firmly stands for alternative routes of gas transportation.

- Bulgaria has until recently benefited from a privileged relationship with the Russian Federation as considered a potential basis for a possible expansion in the Balkans energy market (Postevska, 2010);

- Turkey exerts a senior member influence in the southern Caucasus and in Iraq, providing an alternative energy route Baku-Tbilisi-Ceyhan. The Blue Stream gas pipeline also joins the Russian Federation and Turkey. It's interested to acquire control of alternative transportation routes of gas from the Caucasus region. By controlling the very busy traffic routes in Bosporus and Dardanelles straits, is indirectly the main inhibitor in development of a main transmission system in the Black Sea LNG. In the year 2015 it came into conflict with the Russian Federation, all projects in the energy field between the two countries being cancelled;

- Georgia has a strategic position, allowing control over its territory land routes between the Black Sea and Azerbaijan and between North and South Caucasus. Its territory is crossed by several routes hydrocarbons transport. It had an open conflict with the Russian Federation, being still under the pressure of its;

- Azerbaijan is one of the major natural gas producing States in the region. Main resources identified are located in the water from Shah Deniz, (opened in 2006, is now producing 8 billion cubic meters of natural gas per year, and from 2017, when it will be released the 2 nd operational phase an additional production of 16 billion cubic meters of gas shall be extract) with shareholders like: (FGF) 25.5\%, Statoil (Norway) 25.5\%, Naftiran Intertrade Company (NICO-Iranian company oil and gas corporation headquartered in the United Kingdom) 10\%, Total (France) 10\%, LukAgip (Russia-Lukoil joint venture Agip Italy) 10\%, TPAO (Turkish national company oil and gas) $9 \%-10 \%$ and SOCAR (Azerbaijan) (http://www.bp.com/en). It's interested in the development of alternative routes of transport to bypass Russia.

\section{The main pipeline routes in the Black Sea Area}

In order to counter the trends of Russia to create a "Empire Energy", some researchers believe that the European Union should adopt a coherent and common energy policy based on: creating routes alternative supply to bypass Russian Federation, diversify imports hydrocarbons, making supply contracts with other suppliers strategic interconnecting European transport networks, creation of stocks, improve energy efficiency, develop and implement a common energy policy (Postevska, 2010).

We can say that the existing pipelines can be divided into two categories: those controlled or approved by the Russian Federation or alternative transport routes. 


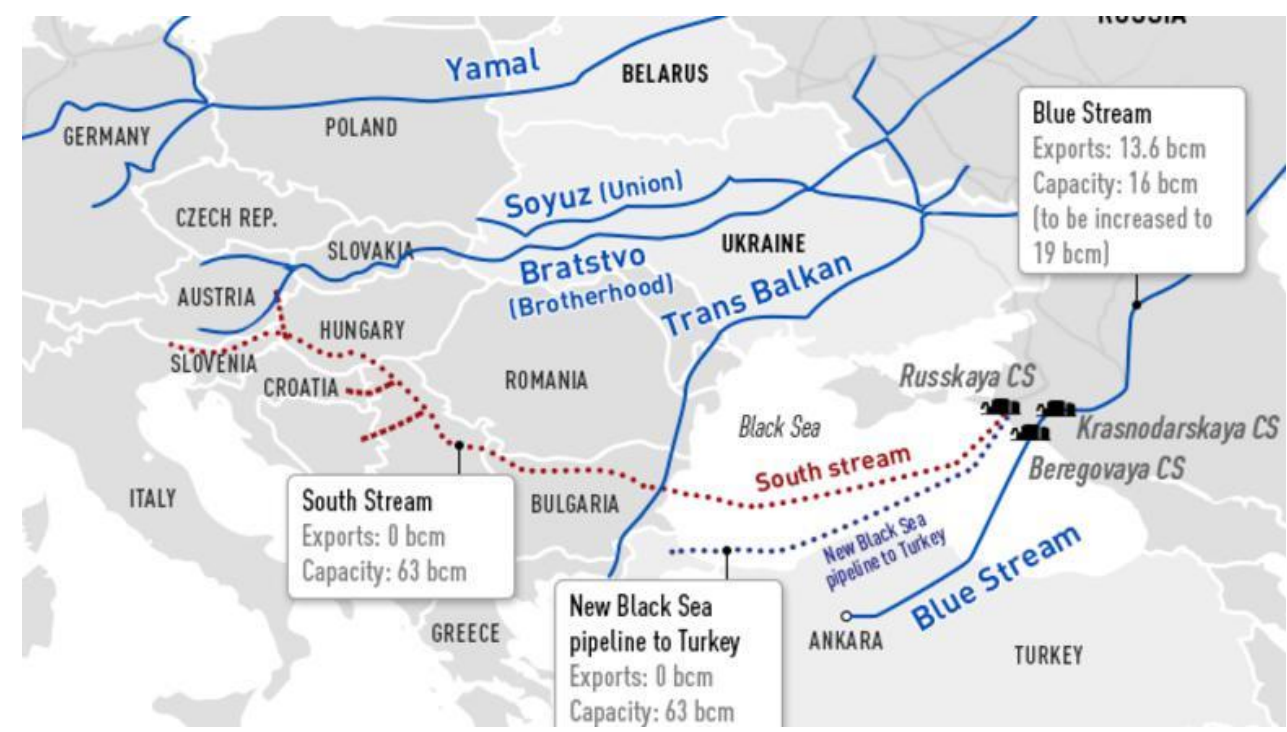

PICBE 86

Figure 2. The main transport routes of Russian gas in the Black Sea area (Iași-Chișinău gas pipeline, we can get rid of Russian blackmail)

Source: Actualitate on March 252016.

\section{Existing pipelines in the Black Sea area (controlled or approved by the Russian Federation)}

The most important oil transport is bus DRUZHBA (Friendship) that is backed by 2 pipelines: Brotherhood pipeline and Soyuz, which have a capacity to transport 40 billions of cubic meters of gas annually.

The Brotherhood pipeline starts from Kazakhstan and joins with Russia-Ukraine pipeline in the middle course of the Volga (Samara). In continuation the pipelines crosses northern Ukraine, heading for the Czech Republic, Slovakia and Germany. (Postevska, 2010)

The southern fork of Kiev, called Soyuz, penetrates up in Hungary. Romania has been connected to the Soyuz, the Ukrainian sector. Another South Eastern branch (Transbalkan) unites the Western Ukraine with southern Moldova and eastern Romania (since 2002), Eastern Bulgaria and northwestern Turkey. Another branch is oriented north to south, in the area of Tbilisi, Georgia. (Postevska, 2010)

The fact that this pipeline is transiting Ukraine represents a major impediment for Gazprom, which is seeking alternative routes for the transport of gas to the Western Europe. (Mionel, 2015).

The pipeline Peninsula of Yamal-Europe, Malnow (Germany), in length of $4196 \mathrm{~km}$ long became operational in 2002, on a part of its length. Between the years 2002-2007 it provided 173 billion transit of $\mathrm{cm}$ 's of gas. (Postevska, 2010)

Blue Stream underwater pipeline, inaugurated in 2005 is linking Stavropol area of the Russian Federation with the port of Samsun, Turkey, crossing the Black Sea. In 2005, Blue Stream has provided transport to 5.1 billion $\mathrm{cm}$, and in 2006 about 7.5 billion $\mathrm{cm}$. (Postevska, 2010, p. 104). Since its launch, the Blue Stream was interpreted as an alternative to the Nabucco project, aimed at bringing gas to Europe from the Caspian Sea area, an attempt by Gazprom to bypass Ukraine and Belarus in an attempt of monopolizing the gas market of Turkey. (Mionel, 2015) 
Nord Stream is operational since 2011, being completed in 2012 as a second pipeline for export. With a total capacity of 55 billion $\mathrm{cm}$ of gas carrying in Germany under the Baltic Sea, bypassing transit countries (the Baltic States and Poland), sparking major complaints from them. (Mionel, 2015)

Pipeline Baku-Tbilisi-Erzerum (Turkey) has become operational in 2006, has a length of $692 \mathrm{~km}$ and a capacity of 20 billion $\mathrm{cm}$ (from 2012). (Postevska, 2010)

\section{Pipeline projects in the Black Sea region expanded Projects abandoned or frozen}

Without claiming having that we had reviewed all pipeline projects in the region, we present the major projects initiated in it. The reasons for cancelling these projects are economic and especially political. All these projects can be classified into the logic of a theory which refers to alternative routes and alternative sources of supply (alternating respective customers for the same resources);

\section{Proposed projects agreed by the Russian Federation/ (alternative for clients the same resources)}

The projects developed by Russian Federation departing from Gazprom attempts to undermine the European Union's objectives regarding alternative routes and alternative sources of supply, acting as providing economic benefits for various state actors in the region, something that creates some antagonistic positions of European countries.

Turkish Strem underwater gas pipeline should supply markets of Turkey, Greece and Italy. Russian Federation froze the project in December 2015 due to a Russian plane shot down in Syria, by the Turkish air force. (Gotev, 2015). The South Stream pipeline that would connect profile networks between the Black Sea and Austria was a competitor of Nabucco. (Postevska, 2010)

\section{Proposed projects agreed by the European Union/ (alternative for clients the same resources)}

European projects have the objective to secure the sources and routes of transportation of natural gas. In addition to the pressures of the Russian Federation, put in a position of losing important clients, and a loss of economic political influence in Europe, the projects proposed by the European Union are hitting often of sometimes antagonistic interests of the Member States.

Gas pipeline Azerbaijan-Georgia-Ukraine-EU (White Stream) was rejected by Ukraine in 2005. (Postevska, 2010)

Transcaspic Gas pipeline aimed to create a path with the exclusion of the Russian Federation. It was abandoned in 2007 at pressures of the Russian Federation. (Postevska, 2010)

Nabucco would function as "alternative energy route" linking Central and Eastern Europe with production capacities of the Caspian Sea basin. The project was abandoned, after long discussions. (Postevska, 2010). 


\section{Major projects of natural gas transport in process}

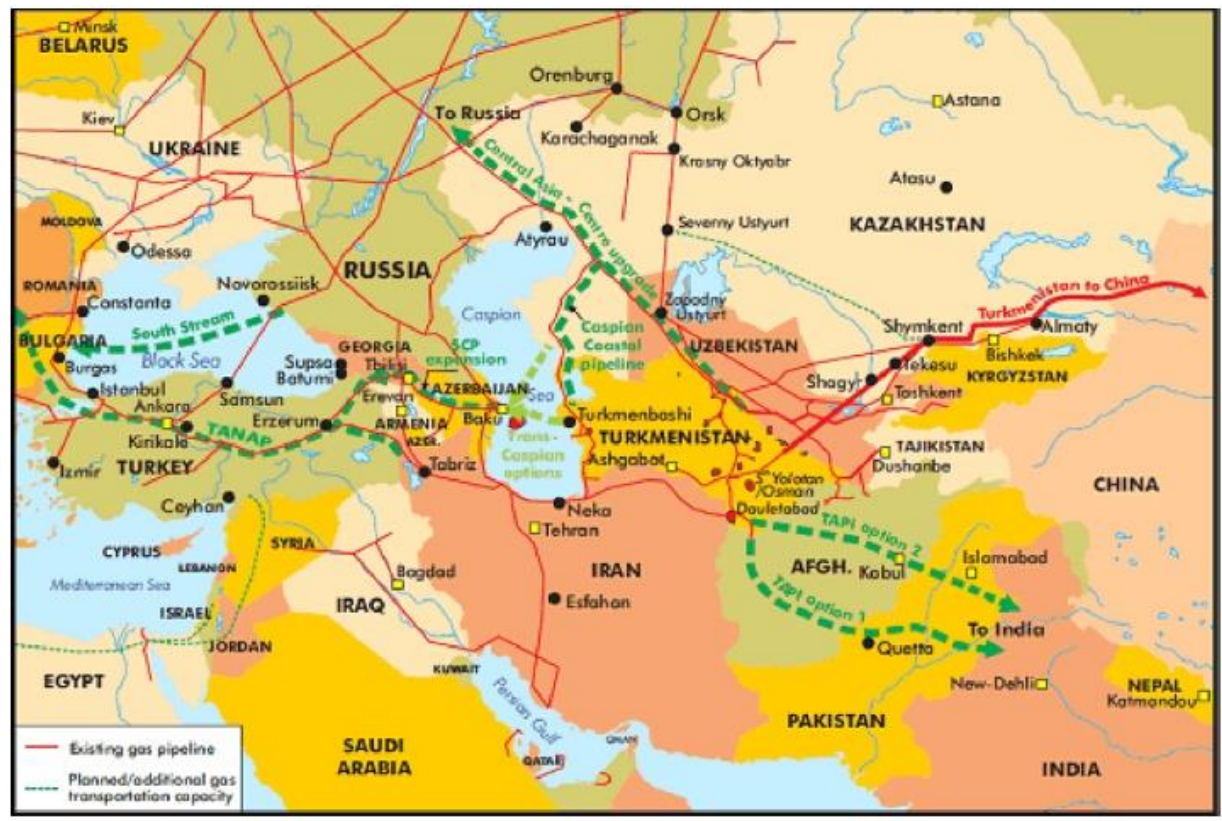

PICBE $\mid 88$

Figure 3. Pipeline projects in the Black Sea region and the Near East

Source: Iuga, Vasile, 2014.

The main projects developed in the Black Sea area gas mainly aim of diversifying routes and sources of gas supply as part of the security strategies of the EU, namely for the countries of the region. Although we make an inventory of all existing projects in the region, we will only present the most discussed ones.

Although not part of the wider Black Sea area, Nord Stream 2 has a huge influence on projects in the region. With estimated costs of $\$ 11$ billion, would be extending Nord Stream gas pipeline with a length of 1,224 kilometers that comes from Russia, passing under the Baltic Sea and arrive in Germany. The project aims to double the capacity of Nord Stream. Gazprom is the only supplier and a major shareholder in Nord Stream 2. The project, announced in September, is being developed by a consortium of Russian and European energy groups: Gazprom, Shell (Anglo-Dutch), BASF (Germany), E.ON (Germany), Engie (France) and OMV (Austria). (Cojocaru, 2015)

Nord Stream 2, supported by Germany, would threaten Ukrainian route of Russian natural gas, which would not be convenient for Romania, Bulgaria and other Eastern European countries because they would lose transit fees. Instead, Nord Stream 2 would bring Russian gas without intermediaries to Germany, bypassing Ukraine and Poland, energy security and geopolitical influence higher. Poland is interested in another project, liquefied natural gas, for which the North Stream 2 will be the competitor. The gas pipeline would not serve the interests of Italy, who could take advantage of the discovery of a huge gas reserve in Egypt and become its European distribution centre. (Cojocaru, 2015)

We believe that this project is likely to be achieved, despite the discontent expressed in public by a number of EU countries, especially as part of the trend seen in the Gazprom in the last decade, meaning increasing transport capacity it projects already existing. 
Southern Corridor is considered by shareholders at the Shah Deniz field gasifier as the most important route of transport production to the final consumer. It involves interconnecting existing infrastructure elements with some newly built:

- The current pipeline - South Caucasus Pipeline (SCP) will be extended with a new parallel and pipeline will traverse Azerbaijan and Georgia;

- Trans-Anatolian Pipeline (TANAP) will ensure transport through Turkey;

- Trans Adric Pipeline (TAP) will supply the gas through Greece, Italy and Albania.

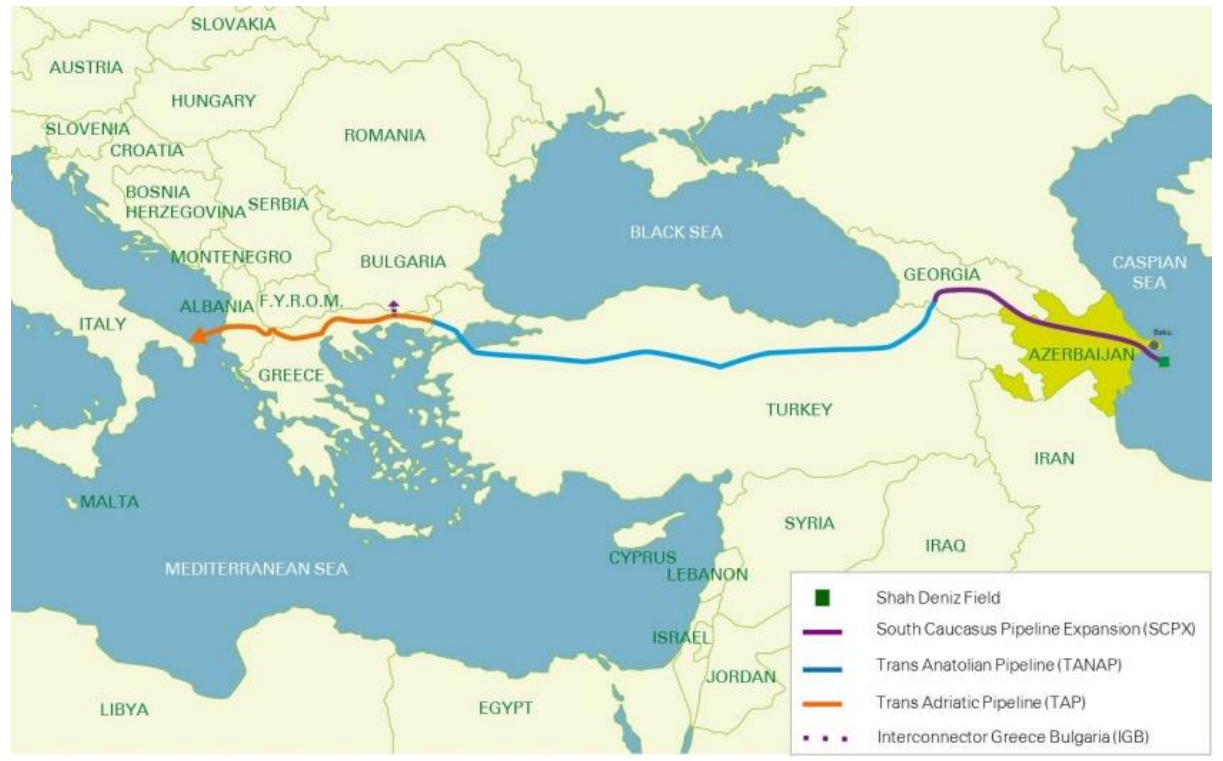

Figure 4. The southern corridor of gas transportation

Source: www.bp.com/en.

It is the only natural gas transportation project developed through the theory of interdependence (distributors' involvement in the production processes or producers in the process of distribution or transit). We believe that this project presents major opportunities to be realized, being designed and realized by a world-class investor consortium. In addition, this project develops in parallel with increasing production capacity of Shah Deniz field gasifier, the most important way to exploit it. ABC (AegeanBaltic Corridor), a project backed by Greece, involves the construction of an LNG terminal, connecting the South with the North in the direction of Greece to Poland, transiting 7 Central and Eastern European countries (Iuga, 2014).

Slovakia has launched the idea of construction for a new route of transport of natural gas to the South-East Europe, named Eastring. The new project would provide the opportunity to carry the gas to the Balkans route bypassing the Russian classic routes. The pipeline would start from Velke Kapusany (Slovakia) on the border with Ukraine, and would end up at the Bulgarian-Turkish border. Eastring would have an annual capacity of transporting up to 20 billion cm, more than Romania's annual necessary, which is about 14 billion $\mathrm{cm}$. The gas to be transported through Eastring would come from Western Europe, passing through Bulgaria, Romania and Slovakia. Eastring would have a length of 570 kilometers, while the investment would amount to 750 million euros. The project involves connecting gas pipe from Slovakia to the Soyuz pipeline from Ukraine, up to the border with Romania, whose territory will have constructed a new segment, and link a main pipeline 
from the Balkan region near the Black Sea. Initially, the gas pipeline will allow the delivery of 10 billion $\mathrm{cm}$ per year, but subsequently the amount could be doubled. The pipeline would operate both ways, which would also allow russian gas transport. (Slovakia is preparing to launch Eastring ...)

In the public space have circulated also similar projects, involving linking north to south of the continent. We believe that a project of this type has little chance of being realized, interconnecting the national transmission systems (measures undertaken at EU level) having the ability to cover, in part, the objectives to build new gas pipelines, which would prove to be ineffective from the economic point of view.

Azerbaijan-Georgia-Romania Interconnector (AGRI) is a project of a transport system for natural gas from Azerbaijan to Central Europe. Form the Sangachal terminal (Azerbaijan on the coast of Caspian Sea) gas is to be pumped through the pipeline to the Georgian Kulevi port on the Black Sea, where it is planned to construct a liquefaction plant. From here, liquefied natural gas (LNG) vessels will be loaded into special tankers and transported to the port of Constanta, where it will be re gaseous and send to the Romanian pipeline system.

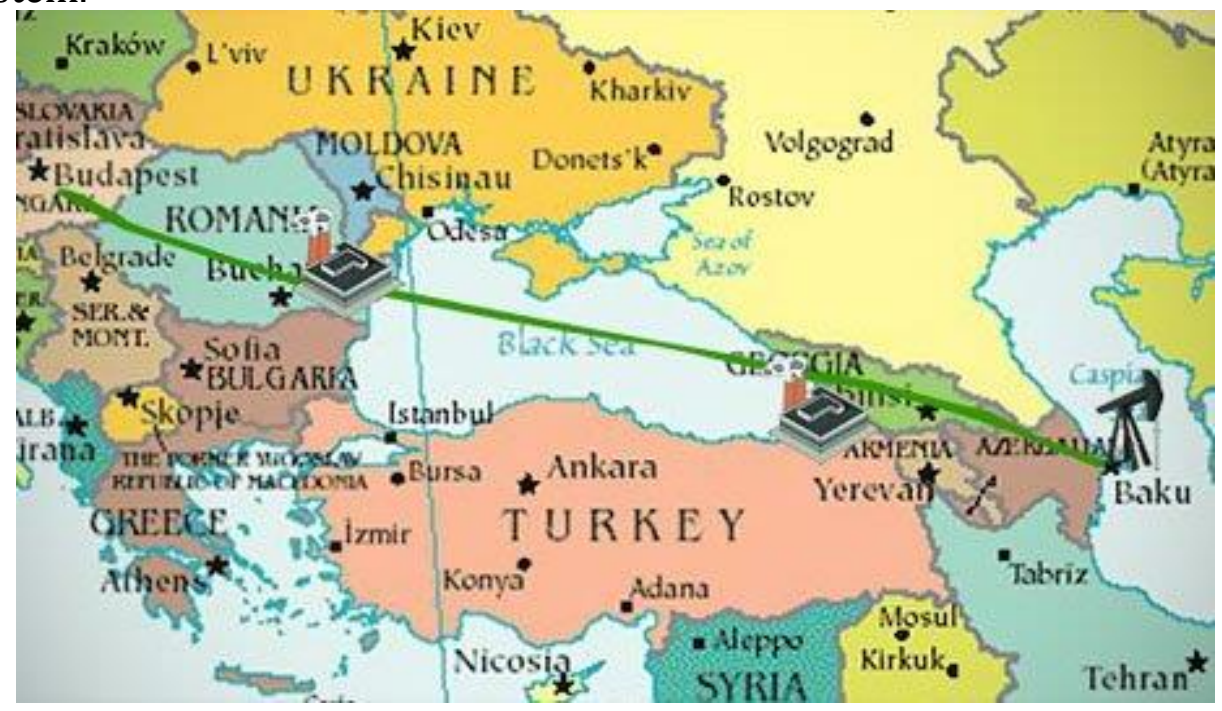

Figure 5. A.G.R.I. Project

Source: www.agrilng.com/ro.

After completing Arad-Szeged pipeline - which in theory will make possible also pumping gas from Romania to Hungary - a significant gas volume will be transported by AGRI and reach the Central European market. In the opinion of the initiators, AGRI project has the potential to become an important tool for ensuring energy security of the European Union in the long term, which shall correspond to double diversification - both supply sources and transit routes. AGRI LNG is the first project to be developed over the Black Sea, which aims to transport gas from the Caspian region to Europe http://www.agrilng.com/ro.

This project has minimal chance of completion; there is a series of insurmountable problems, especially from the economic point of view. However the project is kept on the agenda, mainly for geostrategic reasons.

The decrease in demand, as well as the measures taken as a result of the crisis in Ukraine/Crimea, along with the occupation of the zone-out imports of LPG from United 
States, in conjunction with the decrease in the price of oil worldwide, makes economic capacity for building of major new gas transport inefficient, at least at the present time.

\section{Conclusions}

In the wider context of ensuring economic security, the most important measures in the field of gas supply to the EU and in particular in the extended Black Sea region is developing deposits of gas fields in the region (conventional, those from the offshore Black Sea area, unconventional gas), diversification of supply sources, and interconnection of national transmission and underground storage capacity.

For financing of infrastructure projects possibility of accessing European funds and achieving interconnection between national and bi-directional transit is mandatory, according to Community legislation.

However, analyzing natural gas transportation projects in the wider Black Sea area, we can theorize the existence of two types of projects: those developed by the Russian Federation and those developed by the EU. Gazprom's interest is to control the transport routes of natural gas they produce to European countries, while the European Union is seeking ways and means to secure both routes and sources of supply so as to avoid the Russian monopoly on the European market.

A number of commenters of the European economy state that, in terms of implementation of major transport projects of natural gas, is observed for at least a decade that Gazprom and energy companies in Europe (WCO, Eni, E.ON, Shell) build pipeline only on paper, most likely is that the memoranda and agreements to be signed are nothing more than politics Wells, pipelines, and no stops pumping. (Marchievici, 2015)

With a Gazprom suffering a lot in financial terms and the European economy which seems to not return anytime soon to a substantial increase, Russian Federation does not seek to build Turkish Stream or Nord Stream extensions. Moscow's proposal is not intended only to create divisions between EU: between Germany which is favored by extending Nord Stream and Italy and Greece which would be favored by Turkish Stream; between countries like Romania (which consistently favored projects without Russian participation) and countries like Hungary and Greece (which now favors relations with Moscow), the exclusion or inclusion of these countries on the route of an imaginary gas pipeline, depending on the political interests of the moment.. (Marchievici, 2015)

Economic realities of the present, with a low price of natural gas, a falling demand in the European Union, in conjunction with the entry Iran's entry on the market, make us believe that at least in the next decade, the current capacities of transport are sufficient at the European Union so that the circulation of projects in the field has no economic foundation, but only a geostrategic one.

\section{References}

Bărbuț, D.M. (2012). Strategia energetică în contextul securității moderne, Ed. Top Form, București.

Chifu I. (2011), Energy security strategies in the wider Black Sea Region, Ed. Institutului de Științe Politice și Relații Internaționale, București.

Băhnăreanu C. (2008). Resurse energetice, crize, conflicte, Ed. Militară, București. 
Codoban, A. (2012). Rusia și Europa în cursa pentru energie. Gazul natural: între economie și geopolitică, Ed. Ars Docendi, București.

Cojocaru, B. (2015). Un nou test pentru Europa: Nord Stream 2, noul proiect rusesc de gaze, arată cât de contrare sunt interesele statelor UE, la http://www.zf.ro/businessinternational.

Gotev, G. (2015). Russia shelves Turkish Stream pipeline project, retrieved from PICBE| 92 http://www.euractiv.com/section/europe-s-east/news.

Iordan-Constantinescu N. (2014). The need of a new energy policy in the European Union, in Vasile Simileanu, Flavius Caba-Maria (eds.) - New dimensions of energy strategies in the Middle East and North Africa, Ed. Top-Form, Bucharest.

Iuga, V. (2015). Consideraţii referitoare la securitatea aprovizionării cu gaze naturale în Europa de Sud-Est. Poziţia României, retrieved from http://www.contributors.ro/economie.

Marchievici, C. (2015). Gazoducte pe hârtie. Cel mai bun joc de strategie al Rusiei, retrieved from http://www.cotidianul.ro/gazoducte-pe-hartie-cel-mai-bun-joc-de-strategieal-rusiei-263616/.

Mionel, V. (2015). Resurse geostrategice: geografia economică în arena politicii globale, $E d$. Universitară, București.

Paul, G. (2007). NATO and energy Security, CRS Report for Congress.

Proninska, K. (2007).Energy and security: regional and global dimensions; Yearbook Armaments.

Proninska, K. (2007). Disarmament and International Security, Oxford University Press: 215240.

Postevka, M. (2010) - Politică și energie în Est - cazul Ucrainei, Ed. Top Form, București http://www.digi24.ro/Stiri/Digi24/Economie/Stiri/EASTRING+SLOVACIA+PROIEC T+GAZODUCT+ROMANIA

AGRI (na) The main project to be developed across the Black Sea, retrieved from http://www.agrilng.com/ro.

The Sothern Gas Corridor, retrieved from http://www.bp.com/en_az/caspian/operations projects/Shahdeniz/SouthernCorridor.html. 